\title{
Purveying Patriotic Pageantry: The Civil War Sanitary Fairs in New York
}

\section{Lorraine Madway, Wichita State University Libraries}

$\mathrm{T}$ he elaborate sanitary fairs staged in the United States from 1863 to 1865 to raise money for Union troops during the Civil War did much more than captivate the country. These grand bazaars and expositions relied on a skillful fusion of commerce, consumption, patriotism, and theatricality to promote medical and humanitarian care for soldiers through cultural, commercial, and military displays, exhibitions, and entertainments on a massive scale. The fairs provided opportunities, both spectacular and emotional, for fairgoers to experience themselves as vital participants in the nation's struggle. These pageants became the vehicle for rallying support from a broad range of the civilian population, transcending distinctions of age, class, and gender. The astounding success of the more than twenty fairs held in eleven northern states and the District of Columbia blunted lukewarm support at home and persistent criticism abroad of the Union cause. They succeeded far beyond the original expectations of the agency that nominally oversaw them, the U.S. Sanitary Commission, in celebrating the values of loyalty, sacrifice, and national glory among war weary civilians. That the fairs communicated these values through providing participatory experiences of acquisition and consumption testifies to the originality, insight, and dedication of the largely female volunteers who organized and staffed them (see Figure 1). ${ }^{1}$

1. Dr. Lorraine Madway is Curator of Special Collections and University Archivist at Wichita State University Libraries, Wichita, Kansas. Her primary research interest focuses on the politics of pageantry, ceremony, ritual, and other forms of public display in American history, early modern British history, and Jewish history.

The author wishes to thank Kathy Downes, Associate Dean at Wichita State University Libraries, who read and critiqued several previous drafts of this article.

The Civil War sanitary fairs have been the focus of noteworthy scholarly research. See, for example, William Y. Thompson, "The Sanitary Fairs of the Civil War," Civil War History 4 (March 1958): 51-67; J. Matthew Gallman, "Voluntarism in Wartime: Philadelphia's Great Central Fair," in Maris A. Vinovskis, ed., Toward a Social History of the American Civil War: Exploratory Essays 


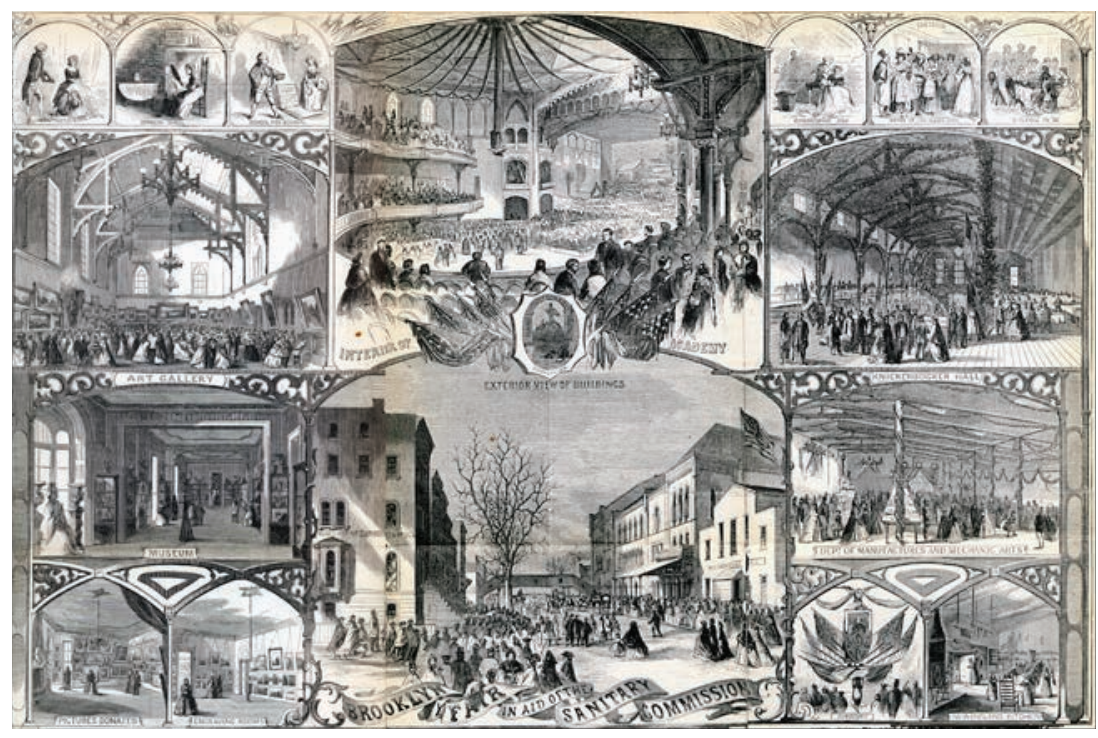

Figure 1. Exterior and interior views of the Brooklyn and Long Island Fair, in History of the Brooklyn and Long Island Sanitary Fair, February 22, 1864, frontispiece. Kantor Rare Book Collection, Special Collections and University Archives, Wichita State University Libraries.

Fair organizers were successful because they persuaded thousands of local residents to contribute goods, services, and time to build and supply the fairs. They then convinced these same residents to join the throngs of visitors who paid to see the exhibits and entertainments and bought the deluge of goods and souvenirs that many of the local

(Cambridge: Cambridge University Press, 1990), 93-116; Jeanie Attie, Patriotic Toil: Northern Women and the American Civil War (Ithaca: Cornell University Press, 1998); Beverly Gordon, Bazaars and Fair Ladies: The History of the American Fundraising Fair (Knoxville: University of Tennessee Press, 1998); Elizabeth Milroy, "Avenue of Dreams: Patriotism and the Spectator at Philadelphia's Great Central Sanitary Fair," in William Blair and William Pencak, eds., Making and Remaking Pennsylvania's Civil War (University Park, Pennsylvania: Pennsylvania State University Press, 2001), 23-57; and Melinda Lawson, Patriot Fires: Forging a New American Nationalism in the Civil War North (Lawrence: University Press of Kansas, 2002), 14-39, 60, 163, 183-184. For a more general discussion of the creation of American nationhood during the Civil War, see Susan-Mary Grant, North Over South: Northern Nationalism and American Identity in the Antebellum Era (Lawrence: University Press of Kansas, 2000); and Peter J. Parrish, The North and the Nation in the Era of the Civil War, edited by Adam I. P. Smith and Susan-Mary Grant (New York: Fordham University Press, 2003).

Figure 1 shows exterior and interior views of the Brooklyn and Long Island Fair, including the Art Gallery, Museum, Engraving Rooms, main hall Bazaar, Knickerbocker Hall, Department of Manufactures and Mechanic Arts, Armory and the New England Kitchen, History of the Brooklyn and Long Island Sanitary Fair, February 22, 1864 (Brooklyn: The Union Steam Presses, 1864), frontispiece. 
people had donated. Both the contributors and the consumers-and many people were both — came to feel a personal connection with the course and outcome of the nation's struggle through demonstrations of popular support. The fairs created an environment that fostered this response by weaving together the material—consumer goods-and the intangible-feelings of patriotism and charity. By the end of the war, sanitary fairs had prompted one of the largest outpourings of popular participation in a single civic movement in United States history. ${ }^{2}$ Yet, the significance of the fairs and New York's prominent role in the movement have, to a great extent, receded from popular memory. This article tells the story of how and why the sanitary fairs became one of the most impressive fusions of public philanthropy and national spectacle in U.S. history, with particular attention to the great success of the New York fairs. It also reflects on the fairs' legacies in achieving their objectives of raising funds for the care of wounded and disabled Union soldiers and their families and for rallying support for the Union cause. ${ }^{3}$ This article draws on the rich array of materials in the Kantor Collection on the U.S. Sanitary Commission and Sanitary Fairs, the second largest collection in the United States of materials documenting the sanitary fairs, housed in Wichita State University Libraries' Special Collections and University Archives. ${ }^{4}$ The comprehensiveness of this collection allows for an analysis of fair activities in almost all the states where they were held and reveals the essential part New York played in sanitary fair history.

The fairs that were held in five cities in New York from December 1863 through April 1864 are a significant yet understudied aspect of

2. The one constituency whose participation was severely limited by fair organizers was African Americans. See J. Matthew Gallman, Mastering Wartime: A Social History of Philadelphia during the Civil War (New York: Cambridge University Press, 1990), 156-57; and Milroy, "Avenue of Dreams," 50, 271, n. 58-60, who discuss the exclusion of African American volunteers and racial restrictions imposed on visitors to the Philadelphia fair.

3. The fair organizers maintained that they also provided care for captured Confederate soldiers, see "Rebel Workmanship for Sale at the Bazaar," edited by "Mr. Smith," in The Canteen, Albany, March 3, 1864, 114, reprinted by The New York State Library, http://www.nysl.nysed.gov/library/ features/ep/pdfs/canteennewsletter.pdf. There is insufficient evidence to determine to what extent Confederate soldiers received medical or humanitarian care from the funds raised by the fairs and the commission.

4. Kantor Collection on the U.S. Sanitary Commission and Sanitary Fairs, MS 92-25, Special Collections and University Archives, Wichita State University Libraries [hereafter cited as Kantor Sanitary Commission \& Sanitary Fairs Collection], http://specialcollections.wichita.edu/collections/ ms/92-25/92-25-A.HTML. A digital collection on the sanitary fairs is accessible at http://cdm15942. contentdm.oclc.org/cdm/landingpage/collection/p15942coll2. 
the Civil War sanitary fair movement. As the northern state with the largest population, and the one that also contributed more soldiers than any other state to the Union cause, New York held more sanitary fairs to raise money to provide medical care and creature comforts for soldiers than any of the other states in the Union. During the course of the Civil War, more than 467,000 soldiers from New York fought, a significant percentage of the total of more than 2.8 million soldiers from the states, territories, the District of Columbia, and those identified with "Indian Nations" and "Colored Troops." 5 The sanitary fairs in New York were held in Rochester in December 1863, Brooklyn and Albany in February-March 1864, Poughkeepsie in March 1864, and New York City in April 1864. These five fairs, comprising almost one quarter of the twenty-one sanitary fairs held during the war, raised more than 42 percent of the total money raised by the sanitary fairs. The Metropolitan Fair in New York City raised about $\$ 2,000,000$, more than any other single fair; the Brooklyn and Long Island Fair raised $\$ 403,000$, the fourth largest amount raised; and the Albany fair raised $\$ 83,000$, the tenth largest amount raised. Thus, three of the ten most profitable sanitary fairs were held in New York. ${ }^{6}$ The historian Harold Holzer points out, "As Lincoln and his contemporaries well knew, New York and its citizens ... remained, throughout the Civil War, crucial to Union success."7

The intended beneficiary of the fairs' fundraising was the U.S. Sanitary Commission. It had developed early in the war under ostensibly benevolent circumstances as supporters of the Union saw a critical need to provide medical and humanitarian care and supplies for soldiers

5. Frederick Phisterer, Statistical Record of the Armies of the United States (New York: Charles Scribner's Sons, 1883), 11.

6. Estimates of total money raised for all the fairs vary from $\$ 5$ million to $\$ 7$ million. See Gordon, Bazaars and Fair Ladies, 11, 66-71; and James Marten, "The United States Sanitary Commission," in David S. Heidler and Jeanne T. Heidler, eds., Encyclopedia of the American Civil War: A Political, Social, and Military History (Denver: ABC-CLIO, 2000), 4: 2004. These amounts range from more than $\$ 71$ million to more than $\$ 99$ million in today's dollars. For a discussion of the various ways to measure the worth of money over time, see the database MeasuringWorth.com, http://www.measuringworth.com/ppowerus/, specifically the webpage explaining how the database makes its calculations.

7. Harold Holzer, State of the Union: New York and the Civil War (New York: Fordham University Press and New York State Archives Partnership Trust, 2001), xvii. As evidence of Lincoln's appreciation for New Yorkers' loyalty, Holzer cites Lincoln's donation in early 1864 of a handwritten copy of a preliminary draft of the Emancipation Proclamation to the Albany Relief Bazzar, ibid., xvii-xviii. 
that exceeded the government's funding and resources. The commission started as an outgrowth of the New York-based Women's Central Association of Relief for the Sick and Wounded of the Army, which turned to a group of socially prominent and ideologically inclined clergy, physicians, businessmen, lawyers, and other eminent citizens for guidance. These individuals saw the commission as an opportunity to engage in social engineering that would benefit the common good by inculcating in others the virtues of order and a disciplined society. They decided to form their own organization and sought official approval from the government during the spring of 1861. In June, President Abraham Lincoln acknowledged the need for civilian help and, with more than a little reluctance, made the commission a government agency led and partly staffed by civilian volunteers. He was said to have remarked at the time that the commission might become "a fifth wheel to the coach" and thus a potentially competing agency to the Army Medical Bureau. ${ }^{8}$

The commission's stated objective was to arrange medical care and sanitary camp inspections for the many volunteer soldiers needed to supplement the small regular army. Its activities included coordinating relief efforts; conducting sanitary inspections of camps; arranging for nurses, hospitals, transportation services, and supplies to supplement the Army Medical Bureau's work; and gathering statistics and other scientific data. Beyond its brief, the commission had a political agenda. Henry Whitney Bellows, its first president and a leading Unitarian minister at the First Congregational Church in New York City, described its role in a revealing letter: The commissioners "acted not merely as a board of military health, but as a kind of Cabinet \& Council of War-boldly seizing anomalous power, advising the Government, \& seeking to influence the men, military and otherwise who command the position." 9 Their advocacy secured the commission's political position. In 1862, its leadership challenged the authority of the Army Medical Bureau and managed to push through the bureau's reorganization and get a Surgeon General appointed who was receptive to the commission's influence. The politi-

8. This oft-quoted attribution to Lincoln is made in William Quentin Maxwell, Lincoln's Fifth Wheel: The Political History of the United States Sanitary Commission (New York: Longmans, Green, 1956), 8, but Maxwell did not document any sources to substantiate his attribution.

9. Henry W. Bellows to Cyrus A. Bartol, September 13, 1861, Bellows Papers, Massachusetts Historical Society [hereafter cited as MHS]. 
cal success of the commissioners did not, however, insure equal success in implementing their philosophical vision.

These leaders were not interested in medical care and the relief of suffering as ends in and of themselves but as part of a social philosophy to reshape American values. One of the commission's reports stated the ultimate purpose of its scientific philanthropy "is neither humanity nor charity. It is to economize for the National service the life and strength of the National soldier." 10 As historian George Frederickson pointed out, "Brutally stated, this meant that the commission saved the soldier in the hospital so that he could die a useful death on the battlefield."11 Leaders emphasized that saving life would reduce the financial cost of the war and preserve the soldier as a "producer" when he "returned to the industrial pursuits of civil life." A report quantified the worth of each soldier's life to the community as "no less than one thousand dollars." 12 A special relief agent for the commission, O.C. Bullard, expressed concern that some wounded and disabled soldiers were not worthy objects of charity and could become a dependent class draining the public's resources." 13

The leadership went even further in reshaping benevolence and saw the suffering of war as a good in itself. Bellows viewed the war as "God's method of bringing order out of chaos." 14 He prayed in the summer of 1861 that the war would lead "to a time of personal sacrifices." Sounding more like a Puritan than a Unitarian, he expressed the wish later that summer that his countrymen might be "gradually schooled to endure hardship." 15 When he visited the Bull Run battlefield in 1862, he was pleased to write that he picked up what he described as "a very nice bone, the hip bone of a loyal hero" and brought it home to show his family and friends. He could not understand why this bone, along

10. Statement of the Object and Methods of the Sanitary Commission, Appointed by the Government of the United States, June 13, 1861, U.S. Sanitary Commission, No. 69 (New York: Wm. C. Bryant \& Co., 1863), 5.

11. George M. Frederickson, The Inner Civil War: Northern Intellectuals and the Crisis of the Union (New York: Harper \& Row, 1965), 102-03.

12. Statement of the Object and Methods of the Sanitary Commission, U.S. Sanitary Commission, No. $69,55-56$.

13. O. C. Bullard to Rev. F. N. Knapp, New York, October 10, 1864, Kantor Sanitary Commission \& Sanitary Fairs Collection, Box 1, FF [file folder] 55.

14. Bellows to his son, September 7, 1862, Bellows Papers, MHS.

15. Bellows to Bartol, April 12, 1861, and August 9, 1861, Bellows Papers, MHS. 
with a skull he also retrieved, "wounded some people's sensibilities."16 Although Bellows was in charge of an organization devoted to humanitarian care, he clearly lacked the empathy to understand that his behavior was not the sort of schooling in hardship to which his countrymen would respond. As the war stretched on and more troops were in the field, Union losses mounted and public support for the war waned. People saw the brutal side of war depicted through the new medium of photography and felt frustrated and discouraged. ${ }^{17}$ Far from dampening the spirit of commission leaders, the losses on the battlefield and in public morale only made them more determined to engage in their rhetoric of chastisement to reinvigorate national life. In Philadelphia in February 1863, Bellows gave a speech that exemplified this strategy. About half way through the remarks, he reminded the audience that there could be no success on the battlefield without "method and rule, and pretty rigid method and rule ... if you could only have real rule, method and habit carried out to the death even, you would have the surest way of attaining to the best results in military affairs." 18 He was particularly dismissive of women's emotional approach to providing care to soldiers: "The women_-God bless them! — think that it requires nothing but a good and loving heart to aid the poor soldiers. But I can assure you, that however ardent and warm the heart, its pulsations, to be effective, must be regulated by order and method."19

Not surprisingly, the commission found it was having difficulty raising funds even though more than 1,500 local aid societies were affiliated with it by late 1862 . Local bazaars and refreshment saloons held throughout the North, even the elaborate ones held in larger cities, were not raising enough money to meet operating expenses. As the war dragged on, civilian morale declined, and this made fundraising even more difficult. The commission only became successful in motivating

16. Bellows to his sister and brother-in-law, March 7, 1862, and to Bartol, April 5, 1862, Bellows Papers, MHS.

17. See, for example, the photographs of Antietam in September 1862, in Selected Civil War Photographs from the Library of Congress, 1861-1865, http://memory.loc.gov/ammem/cwphtml/ cwphome.html

18. Bellows, Speech of the Rev. Dr. Bellows, President of the United States Sanitary Commission: Made at the Academy of Music, Philadelphia, Tuesday evening, Feb. 24, 1863 (Philadelphia: C. Sherman \& Co., 1863), 15.

19. Ibid., 15-16. 
the public to model wartime volunteerism and demonstrate the Union was worthy, as the historian Frances Clark argues, "to reclaim America's role as a redeemer nation," when it relinquished the framework of an organization that was centrally controlled and dominated by men. ${ }^{20}$ The lasting achievements of the Sanitary Commission resulted from the evolution in its strategy from indoctrinating the public to supporting the celebratory efforts of sanitary fairs that were locally organized and largely staffed, and sometimes even managed, by women. Local fair organizers were convinced that raising money for soldiers' medical care could be accomplished not through philosophizing about social engineering but by promoting broad-based grassroots support for the Union cause. That meant articulating the values the Union was fighting for in terms that ordinary people could relate to, and inspiring people to contribute time, goods, and services as well as money. At first skeptical of the fairs' potential, commission leaders came to appreciate their value so much that they ultimately did their best to take back charge of them. ${ }^{21}$

The two women most responsible for the success of the sanitary fairs were Mary Livermore and Jane Hoge. They served as associate managers of the Chicago office of the commission, and their extraordinary vision, energy, and organizing skills allowed them to devise and implement the strategy of grand patriotic celebrations that were locally managed yet national in scope. Livermore was an able planner and administrator, and Hoge was an eloquent public speaker and adept at public relations. By the autumn of 1863 , both women recognized that they had to think of a more effective alternative to the commission's previous refreshment saloons and modest local fairs for reaching the broad public and increasing support for the war. They developed the idea of a grand-scale regional event to raise more funds and encourage greater citizen involvement. The "gentlemen of the Commission" reacted skeptically to their proposal and, as Livermore later wrote, they "were doubtful of its success....

20. Frances Clark, “'Let All Nations See': Civil War Nationalism and the Memorialization of Wartime Volunteerism," Civil War History 52:1 (2005): 93.

21. Gordon, Bazaars and Fair Ladies, 92. Lists of fair organizers prominently display the names of men; for example, all the members of the Advisory Committee of the Brooklyn and Long Island Fair were men, History of the Brooklyn and Long Island Sanitary Fair, February 22, 1864, 17; and the chairmen of all the Special Committees of the Metropolitan Fair, except for the Children's Department, were men, A Record of the Metropolitan Fair in Aid of the United States Sanitary Commission, Held at New York, in April 1864 (New York: Hurd and Houghton, 1867), 242-257. 
[They] languidly approved our plan, but laughed incredulously at our proposal to raise $\$ 25,000$." 22 Much to the surprise of the leadership, the Great Northwest Fair, as it was named, raised at least 150 percent above this amount, with estimates varying from $\$ 60,000$ to more than $\$ 78,000$, which were unprecedented sums at the time for a single charitable event open to the general public. ${ }^{23}$ News spread quickly throughout the North, and the fair became a template for the other twenty fairs held during the next two years in cities throughout the Union, including the border states of Maryland and Missouri. ${ }^{24}$ Organizers in the various cities, particularly major ones such as New York and Philadelphia, competed to make their fairs grander and more spectacular and raise more money than those that preceded them. The fairs were highly profitable and fair organizers often built large enclosed structures for all the exhibitions and other events that took place during the fair, such as those built for the Metropolitan Fair in New York (see Figure 2). ${ }^{25}$

Particular elements made the sanitary fairs successful in instilling a sense of nationhood and arousing loyalty in ways the commission's proselytizing efforts had failed to achieve. The content and tone of the displays and entertainments at the fairs were part of the Union's ongoing political struggle to define the objectives for which it was fighting and contrasted sharply with the commission's ideological messages.

Instead of preaching the virtues of sacrifice and suffering, the organizers offered visitors a stimulating and pleasurable way to show their support for the Union. Visitors' attendance at the exhibits enabled them to witness and participate in the past and present glory of the American nation. The Rochester Christmas fair in December 1863, for example,

22. Mary Livermore, My Story of the War: A Woman's Narrative of Four Years Personal Experience as Nurse in the Union Army, and in Relief Work at Home, in Hospitals, Camps, and at the Front, during the War of the Rebellion (Hartford: A. D. Worthington \& Company, 1892), 412, 411.

23. The Sanitary Commission estimated the fair raised about $\$ 60,000$, Kantor Sanitary Commission \& Sanitary Fairs Collection, Box 1, FF 39; Box 8, FF 5; Gordon estimates it raised more than $\$ 78,000$, Bazaars and Fair Ladies, 65 . The amount originally promised, $\$ 25,000$, has the equivalent value of about $\$ 462,000$ in today's dollars; the estimates of money raised range from $\$ 1,110,000$ to $\$ 1,440,000$ in today's dollars.

24. In addition to the five cities in New York, the other cities included Chicago (twice), Portland, Boston (twice), Cincinnati, Cleveland, Washington, D.C., Baltimore, St. Louis, Pittsburgh, Philadelphia, Dubuque, Springfield, St. Paul, and Milwaukee; see Gordon, Bazaars and Fair Ladies, $66-71$.

25. Opening of the Metropolitan Fair, New York, illustration in Frank Leslie's Illustrated Newspaper, April 16, 1864, 61, Kantor Sanitary Commission \& Sanitary Fairs Collection, Box 6, FF 10. 


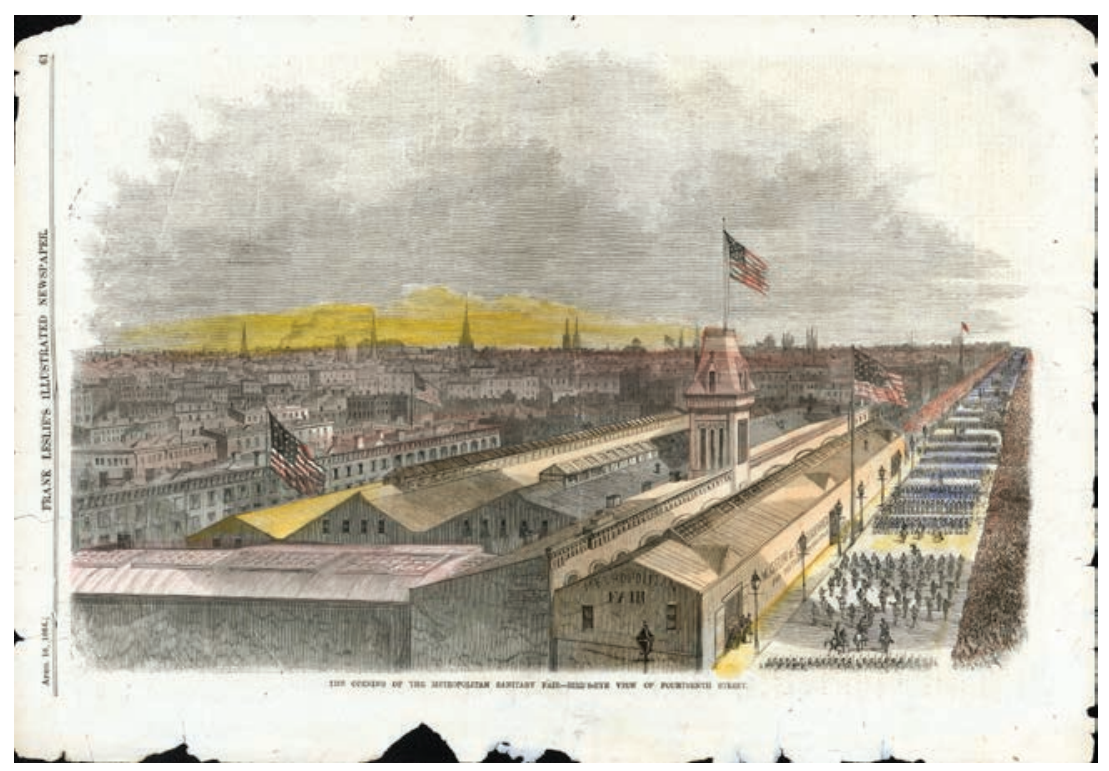

Figure 2. Opening of the Metropolitan Fair, New York, in Frank Leslie's Illustrated Newspaper, April 16, 1864, page 61. Kantor Collection on the U.S. Sanitary Commission and Sanitary Fairs, Special Collections and University Archives, Wichita State University Libraries.

pioneered the use of costumed characters and "living wax works" tableaux, which heightened the sense of theatricality and spectacle and made the audience an essential element of the performance. The organizers were not trying to change human nature but, rather, to harness the best of it for a good cause. They understood that people tend to give more when they get something in return. What the fairs gave visitors was a series of locally accessible celebrations, equally mesmerizing and uplifting, in which visitors could be not just spectators but eager participants. The organizers of the 1864 Metropolitan Fair in New York showed their grasp of the sanitary fair's essential purpose and appeal in a planning report:

[I]t must be universal in its attractions, enlisting all sympathies, pleasing all healthy tastes, and satisfying all honest needs. It must be democratic, but not vulgar; elegant, but not exclusive; fashionable, but not frivolous; popular, but not mediocre. . . . 
Such a universal end as this can only be reached by a Fair which, forsaking the modern notion, returns to the original one, which was a temporary market for merchandise and produce of all kinds, at which commercial ends were reached through vast gatherings of people, and consequent social festivity. . . [W] can have, for a fortnight, a great market, at which shall be exposed for sale every kind of product which our soil or our factories afford, every kind of goods which our merchants import, and which shall be made the occasion of an unusual display in all the departments of artthe whole being animated and hallowed by the same humane and patriotic purpose. ${ }^{26}$

As purveyors of patriotic pageantry, the sanitary fairs transcended the socio-economic origins of their elite organizers and embraced the populist ethos of the marketplace. The fairs combined the atmosphere of traditional bazaars with more sophisticated musical and theatrical performances; displays of curiosities, relics, and weaponry; elaborate exhibits of horticultural, artistic, commercial, and industrial achievement; and opportunities for contribution, acquisition, and consumption that animated visitors while providing them with the opportunity to support the war effort. The textile historian Beverly Gordon argues that the fairs "created a Union-wide showcase of objects and ideas that functioned in the aggregate as a kind of national exposition." 27

Images and descriptions from fairs held in New York provide visually compelling examples of the cultural and commercial offerings available to fairgoers. Displays of curiosities and relics, which included Native American and colonial weapons and artifacts, work implements, and natural specimens, provided visitors with concrete reminders of the nation's past and present and conveyed that it had a "useable past" to celebrate and commemorate. The arms and trophies departments at the Albany and Metropolitan fairs attracted a great many visitors and received extensive coverage in descriptive catalogs. The displays at both fairs included hundreds of items belonging to the State of New York, which were part of a collection deposited at the Bureau of Military

26. Metropolitan Fair, in Aid of the United States Sanitary Commission (New York: Charles O. Jones, 1864), 4-5.

27. Gordon, Bazaars and Fair Ladies, 79. 


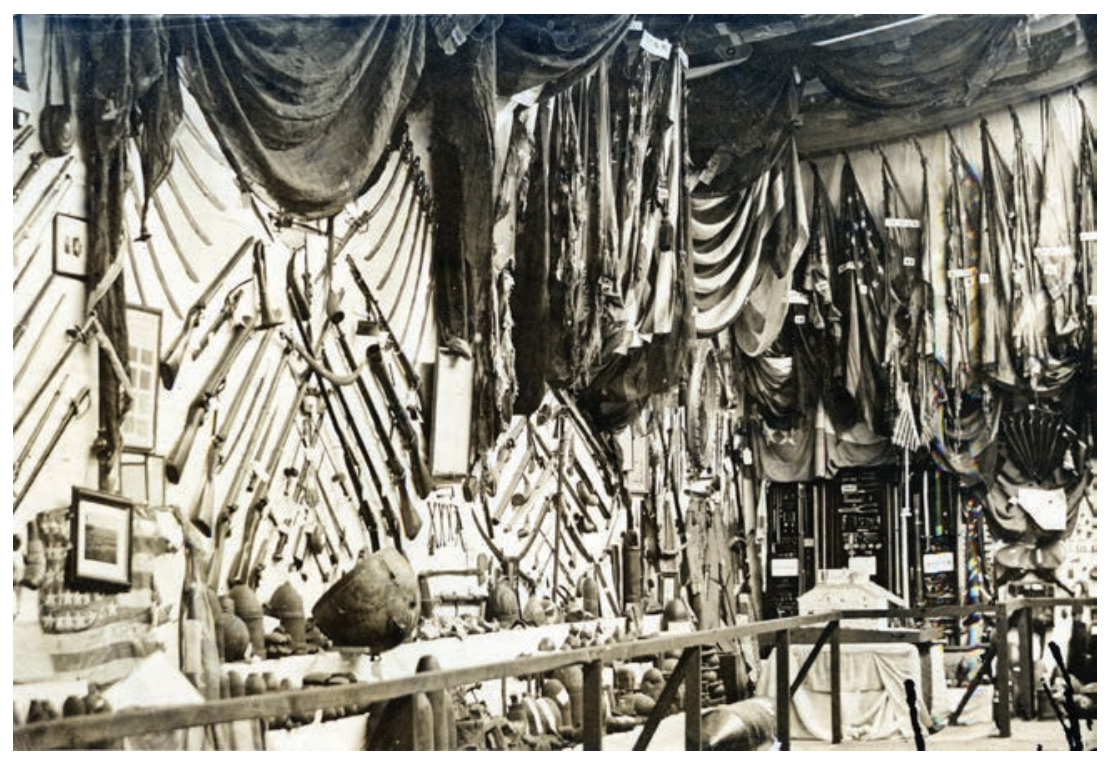

Figure 3. Arms and Trophies Room, Metropolitan Fair, New York, April 1864. Photograph by J. Gurney and Son in A Record of the Metropolitan Fair in Aid of the United States Sanitary Commission, page 34. Kantor Rare Book Collection, Special Collections and University Archives, Wichita State University Libraries.

Statistics at Albany, as well as many other items contributed by dealers and private individuals. The catalog for arms, trophies, and relics from the Albany fair runs more than fifty pages and lists a total of 551 items, and the catalog from the Metropolitan Fair runs more than a hundred pages with a total of 1,022 items. ${ }^{28}$ A photo of the Arms and Trophies Room at the Metropolitan Fair shows the abundance of weapons on display alongside a seemingly endless collection of war relics, artifacts, flags, and banners (see Figure 3). ${ }^{29}$ The sheer size and popularity of

28. Descriptive Catalogue of the Collection of Flags, Trophies and Relics, Exhibited by the Bureau of Military Statistics, at the Army Relief Bazaar, Held at Albany, N.Y., February 22, 1864, $2^{\text {nd }}$ edition enlarged (Albany: Weed, Parsons and Company, 1864); Catalogue of the Museum of Flags, Trophies and Relics Relating to the Revolution, the War of 1812, the Mexican War, and the Present Rebellion, Forming the Most Complete and Interesting Collection Ever Brought Together in the United States: To Be Exhibited at New York, April 4, 1864, and on the Succeeding Days, for the Benefit of the United States Sanitary Commission (New York: Charles O. Jones, 1864); see also Spirit of the Fair, Thursday, April 7, 1864, No. 3 (New York: John F. Trow, 1864), 28.

29. Arms and Trophies Room, Metropolitan Fair, New York, April 1864, photograph by J. Gurney and Son, in A Record of the Metropolitan Fair in Aid of the United States Sanitary Commission, 34. 
the displays and the interest in featuring them in catalogs attest to the importance of these collections to organizers and visitors alike. However slow the progress of the war, the impressive array of weaponry reassured visitors of the superiority of Union might and reminded them to support the cause to hasten its ultimate victory.

At the Metropolitan and Brooklyn fairs, displays provided the backdrop for historical enactments and entertainments. The New England Kitchen at the Brooklyn and Long Island Fair in February-March 1864 was designed to offer, according to the fair's official history, a quaint picture of colonial life "to reproduce the manners, customs, dress, and if possible, the idiom of the time." ${ }^{30}$ It featured tableaux of characters, such as a corn husker, spinners, quilters, and George and Martha Washington. Visitors to the fair could also experience entertainments, such as an "olden time" concert, a quilting party, a visit to the parson, an apple bee, and a wedding, all of which evoked the pleasures of colonial life while conveniently omitting the hardships. The success of the entertainments made the kitchen, in the opinion of the fair's organizers, "the funny feature of the Fair," thereby undercutting its original purpose "to illustrate the domestic life and habits of the people, to whose determined courage, sustained by their faith in God, we owe that government, so dear to every loyal heart." 31 No mention of colonial or revolutionary political struggle appeared during the entertainments to erode the aura of domesticity even though "[t]he period fixed upon" was "just prior to the throwing overboard of the tea in Boston Harbor" in 1773."32 Visitors to the Metropolitan Fair looking for a New Netherland version of colonial "authenticity" to complement the New England Kitchen at the Brooklyn fair were able to view a fully operational Knickerbocker Kitchen that depicted the cozy domesticity of early Dutch settlers. In the nearby dining areas of the fairs, visitors went from spectators to participants as they ate the types of foods exhibited in the kitchens.

Another important series of entertainments focused on performances by Native Americans. The Brooklyn and Long Island Fair included entertainments in its New England Kitchen of an "Indian"

30. History of the Brooklyn and Long Island Sanitary Fair, February 22, 1864, 73.

31. Ibid., 72-73.

32. Ibid., 73 . 
whose behavior, recorded in the official history, struck a bellicose and savage pose:

Now and then an Indian, hideous in horns and paint, would stalk solemnly through the crowd, and one could almost feel the scalp creep uneasily on his head, as he thought of those wild men of the forest, whose visits to the kitchens of our ancestors were not unfrequently [sic] the premonitions of the blazing home, and the midnight massacre. 33

The organizers of the Metropolitan Fair devised a separate Indian Department and artist Albert Bierstadt oversaw nineteen or twenty Natives who performed a dozen ceremonial dances, including a war dance and a scalp dance. The dancers were often featured in newspaper articles publicizing the fair (see Figure 4), and a photograph of them was included in the official history of the fair (see Figure 5). ${ }^{34}$ The available evidence supports the dancers' native origins, but raises questions as to their tribal affiliations. The caption under the Indian Department on the ground plan in The New York Herald described them as "Bierstadt's Rocky Mountain Indians Shoshone Tribe."35 A New-York Tribune article said the group included several who accompanied Bierstadt on his western trip as well as a Cayuga, and the others were Onondagas from near Syracuse. ${ }^{36}$ Only the official history of the fair questioned their origins: "The red men were from the Rocky Mountains, or from the wilds of Mackerelville, according to the spirit of the narrator; they were the subjects alike of romances and of jokes." 37 The official record evoked the stereotypes of the "noble savage" and the "bloodthirsty savage" in

33. Ibid., 75 .

34. See, for example, the cover illustration of the dance performance at the Metropolitan Fair, in Demorest's New-York Illustrated News, April 23, 1864, vol. IX, no. 234, Kantor Sanitary Commission \& Sanitary Fairs Collection, Box 6, FF 4; photograph by J. Gurney and Son, in A Record of the Metropolitan Fair in Aid of the United States Sanitary Commission, following 50.

35. The New York Herald, April 4, 1864, 1, Kantor Sanitary Commission \& Sanitary Fairs Collection, Box 6, FF 13.

36. The New-York Tribune, April 5, 1864, 1, 8, Kantor Sanitary Commission \& Sanitary Fairs Collection, Box 6, FF 16.

37. A Record of the Metropolitan Fair in Aid of the United States Sanitary Commission, 49. Mackerelville refers to the area of Manhattan now located between $11^{\text {th }}$ and $13^{\text {th }}$ Streets and $1^{\text {st }}$ Avenue and Avenue C. 


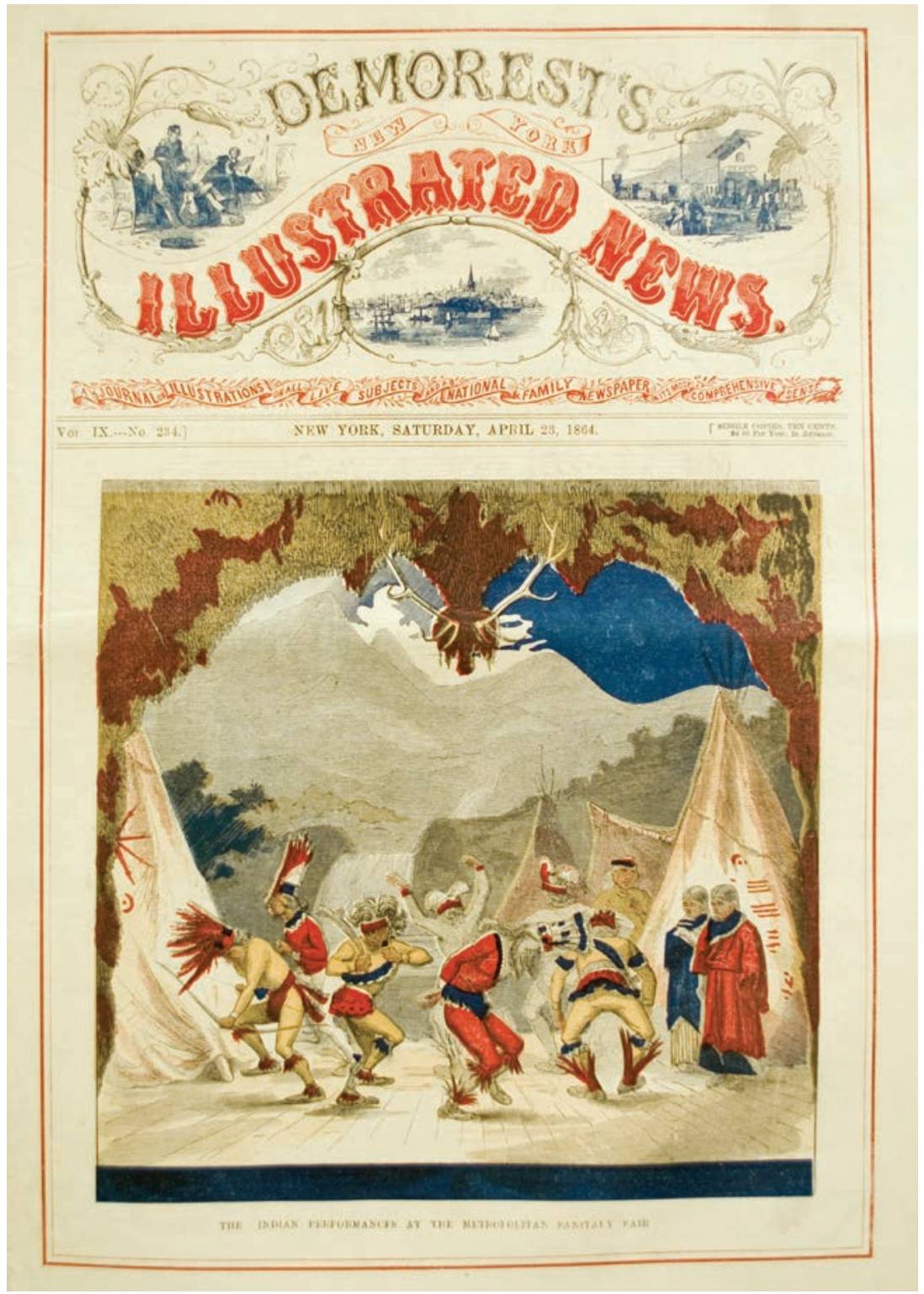

Figure 4. Native American dance performance at the Metropolitan Fair, New York, on the cover of Demorest's New-York Illustrated News, April 23, 1864. Kantor Collection on the U.S. Sanitary Commission and Sanitary Fairs, Special Collections and University Archives, Wichita State University Libraries. 

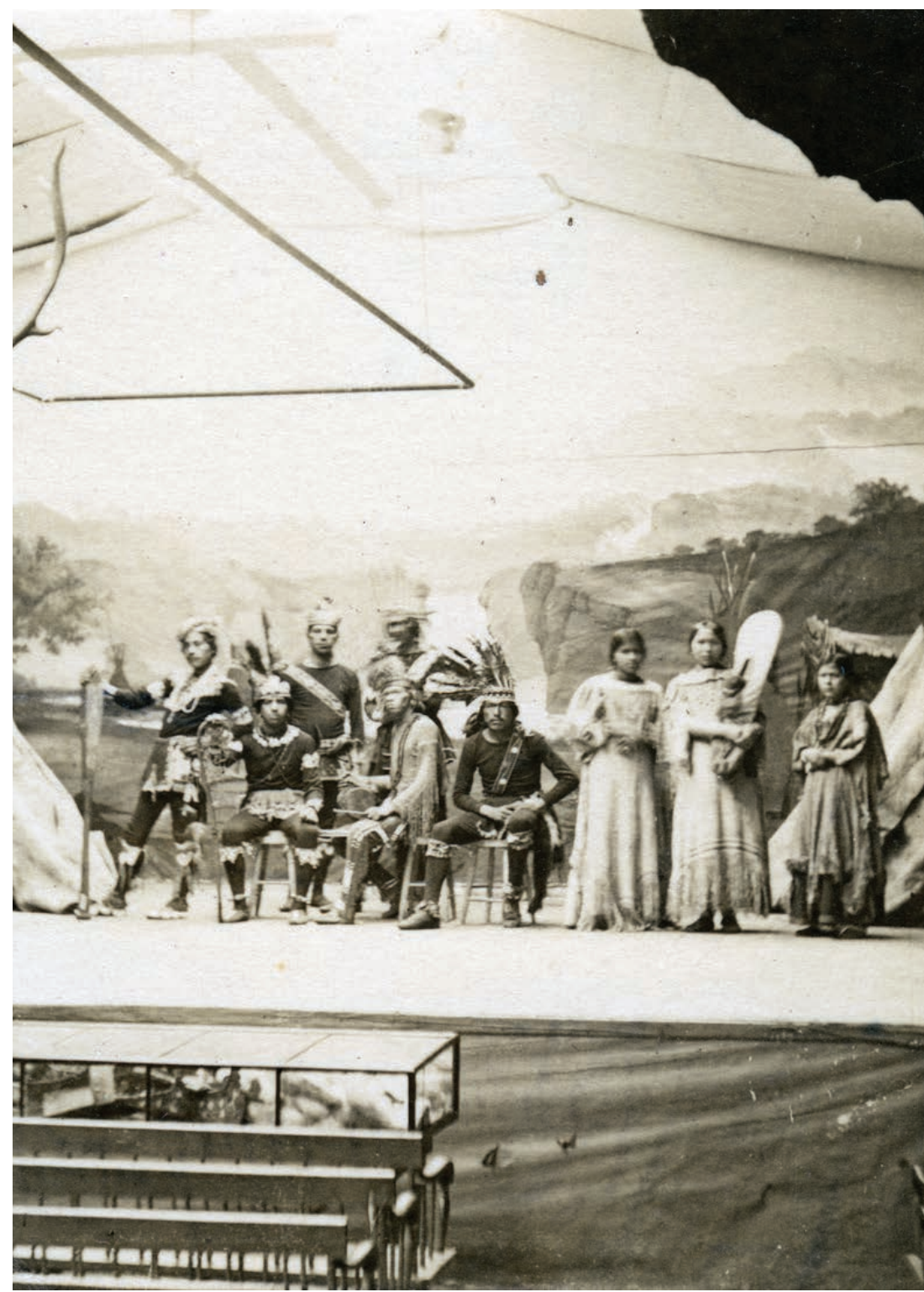

Figure 5. Native American dance performers at the Metropolitan Fair, New York, April 1864. Photograph by J. Gurney and Son in A Record of the Metropolitan Fair in Aid of the United States Sanitary Commission, page 50. Kantor Rare Book Collection, Special Collections and University Archives, Wichita State University Libraries. 
its account of "a genuine spectacle of some of the savage rites." 38 While conceding the generosity of the dancers who "offered their services without mention of compensation," the report reveals fair organizers perceived more evidence of native savagery than nobility in the performances of "a series of dances that were more than corybantic in execution-muscular savagery fairly distancing muscular Christianity in their common fold."39 The performances, which occurred amidst a display of native artifacts and next to a large wigwam, reassured spectators that the triumph of white settlement was achieved over opponents whose ferocity and artistry made them worthy objects of conquest. ${ }^{40}$

Elaborate horticultural displays were a source of amazement since at this time few botanical gardens or grand public parks existed in the United States. The substantial space and prominent placement allotted to floral departments, as shown in the ground plan of the Metropolitan Fair for the "Floral Temple" (see Figure 6), indicated the importance of these displays. ${ }^{41}$ Even the ground plan at the smaller Brooklyn fair shows space allotted to a fishing pond and water (see Figure 7). ${ }^{42}$ Admittedly, the horticultural displays at the New York fairs did not compare to those presented at the Great Central Fair in Philadelphia in June 1864. That fair's organizers were eager to feature exhibits surpassing those at the Metropolitan Fair whose organizers had managed to open two months earlier and garner the attention and prestige of opening first. Nevertheless, the horticultural exhibits at the New York fairs provide evidence of the mechanical ingenuity and aesthetic and environmental sensibilities of the nation and countered those European critics

38. Ibid., 50. Some newspaper articles about the dance performances were even more pointed in their descriptions of "the rude dwellers in the forest"; see, for example, The New York Herald, April 4, 1864, 2. Extensive discussion of native stereotypes is found in Philip J. Deloria, Playing Indian (New Haven: Yale University Press, 1998).

39. A Record of the Metropolitan Fair in Aid of the United States Sanitary Commission, 50, 52.

40. For an opposing view of these performances at the Metropolitan Fair, see Milroy, "Avenue of Dreams," who argues that the dances at the Great Central Fair in Philadelphia, done by the same Native performers who were at the Metropolitan Fair, were "peaceable," 50, 52, 271, n. 61. However, the illustration in Demorest's, the official photo and account of the dancers at the Metropolitan Fair, and the description of the "Indian" entertainer at the New England Kitchen of the Brooklyn Fair, all refute Milroy's observation that "[o]nly contemplative, peaceable, or assimilated Indians appeared," 50 .

41. Ground plan of the Metropolitan Fair, in Spirit of the Fair, Tuesday, April 19, 1864, No. 13, 147.

42. Ground plan of the Brooklyn and Long Island Fair, in History of the Brooklyn and Long Island Sanitary Fair, February 22, 1864, following 173. 

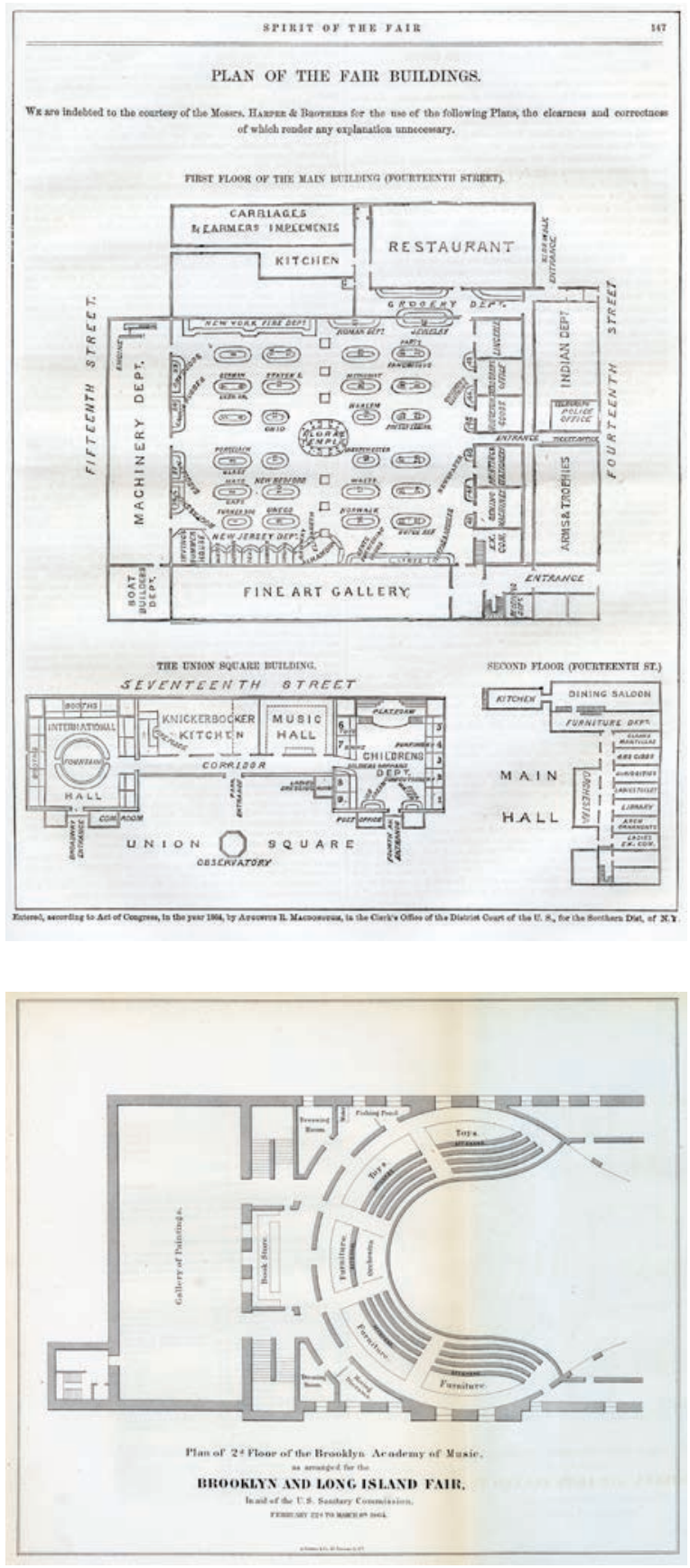

Figure 6. Ground plan of the Metropolitan Fair, New York, in Spirit of the Fair, Tuesday, April 19, 1864, No. 13, page 147. Kantor Rare Book Collection, Special Collections and University Archives, Wichita State University Libraries.
Figure 7. Ground plan of the Brooklyn and Long Island Fair, in History of the Brooklyn and Long Island Sanitary Fair, February 22, 1864, following page 173. Kantor Rare Book Collection, Special Collections and University Archives, Wichita State University Libraries. 
who claimed the Union cared only about material and monetary matters and lacked the refinement expected of a civilized nation.

The display of visual arts was one of the most popular attractions in a country that had few museums at the time. For some of the fairs, even the broadsides promoting them provided an opportunity to enlist art in the service of patriotism. A broadside from the Brooklyn and Long Island Fair provides a vivid rendering of "In Right Is Might." It depicts an avenging, sword-wielding Union angel fighting a hissing Confederate serpent standing underneath a classical arch, along with Gettysburg battle scenes, nurses aiding a wounded soldier, George Washington draped in Roman garb in front of an American flag, and a charitable donation certificate embossed on a shield decorated with stars and stripes (see Figure 8). ${ }^{43}$

Another broadside from the Brooklyn and Long Island Fair, published in Harper's Weekly, depicts Winslow Homer's illustration of the fair's post office. Interestingly, it manages to convey a sexual dimension to patriotic display. Five women are clearly visible: two women standing in the foreground, one staffing the window and waiting on a soldier and the other posting a message on a wall for mittens, and three in the background, one writing a letter, one wearing earphones so she can send or receive a telegram, and another reading a letter. All are young and attired in modest yet fashionable dresses. For the four most clearly visible, their hair is arranged to fall over their shoulders, and the central figure is wearing prominent earrings. Each is posed to show her figure to best advantage. The visual message is that soldiers or other fair visitors will find a trip to the post office pleasurable and helpful in equal measure since it offers a socially acceptable meeting place for young men and women (see Figure 9). ${ }^{44}$

The Albany Army Relief Bazaar broadside displayed four marble sculptures made and donated by a local sculptor, Erastus Dow Palmer: Alexander Hamilton, Good Morning, Peace in Bondage, and Little Peasant.

43. "In Might Is Right" broadside, Brooklyn and Long Island Fair, February 1864, lithograph by S. J. Guy and printed by Endicott \& Company, Kantor Sanitary Commission \& Sanitary Fairs Collection, Box 4, FF 14.

44. "Any Thing for Me, If You Please?" broadside, Post Office, Brooklyn and Long Island Fair, February, 1864, lithograph by Winslow Homer, in Harper's Weekly, March 5, 1864, 156, Kantor Sanitary Commission \& Sanitary Fairs Collection, Box 4, FF 18. 


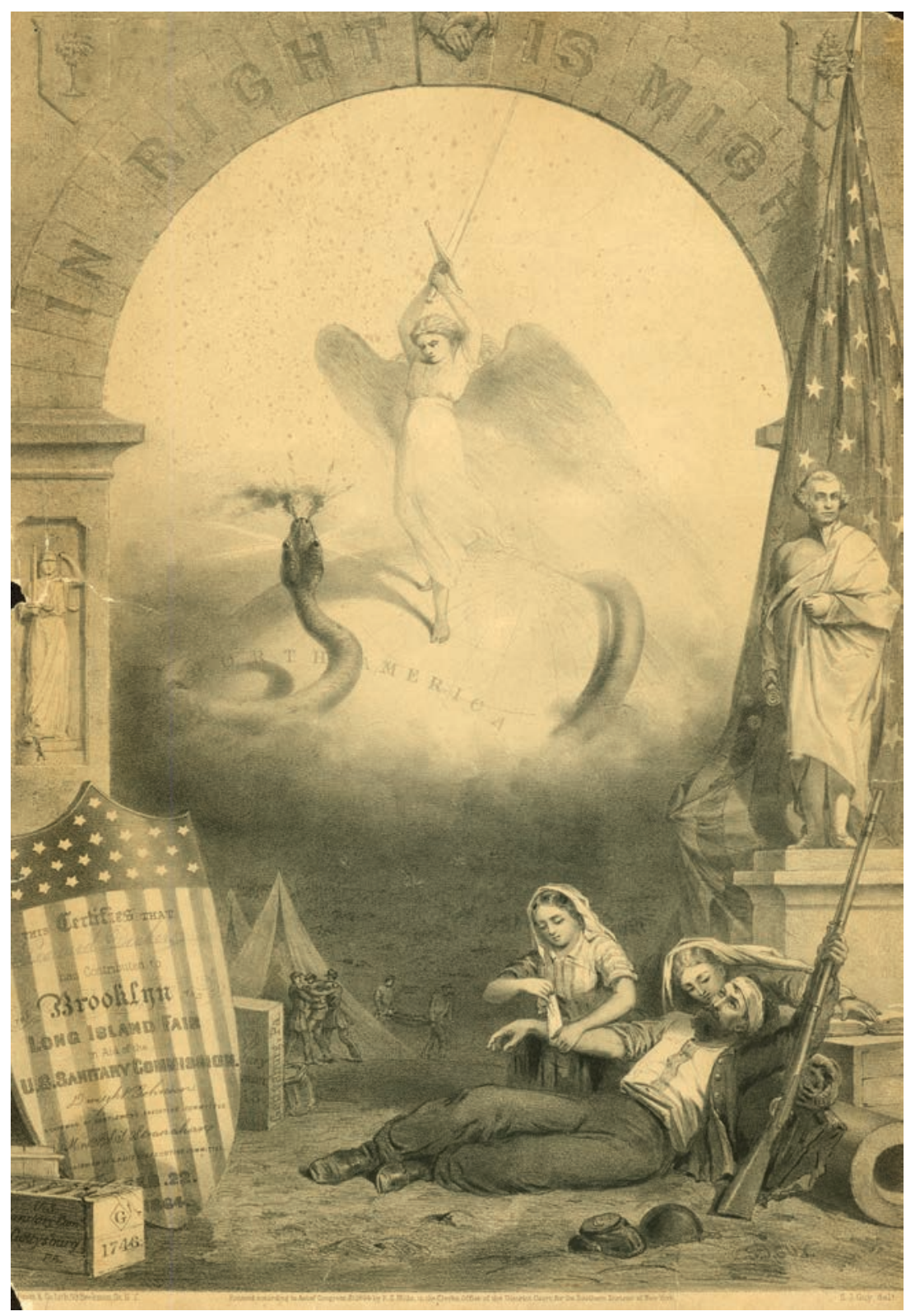

Figure 8. "In Might Is Right" broadside by S. J. Guy, Brooklyn and Long Island Fair, February 1864. Kantor Collection on the U.S. Sanitary Commission and Sanitary Fairs, Special Collections and University Archives, Wichita State University Libraries. 


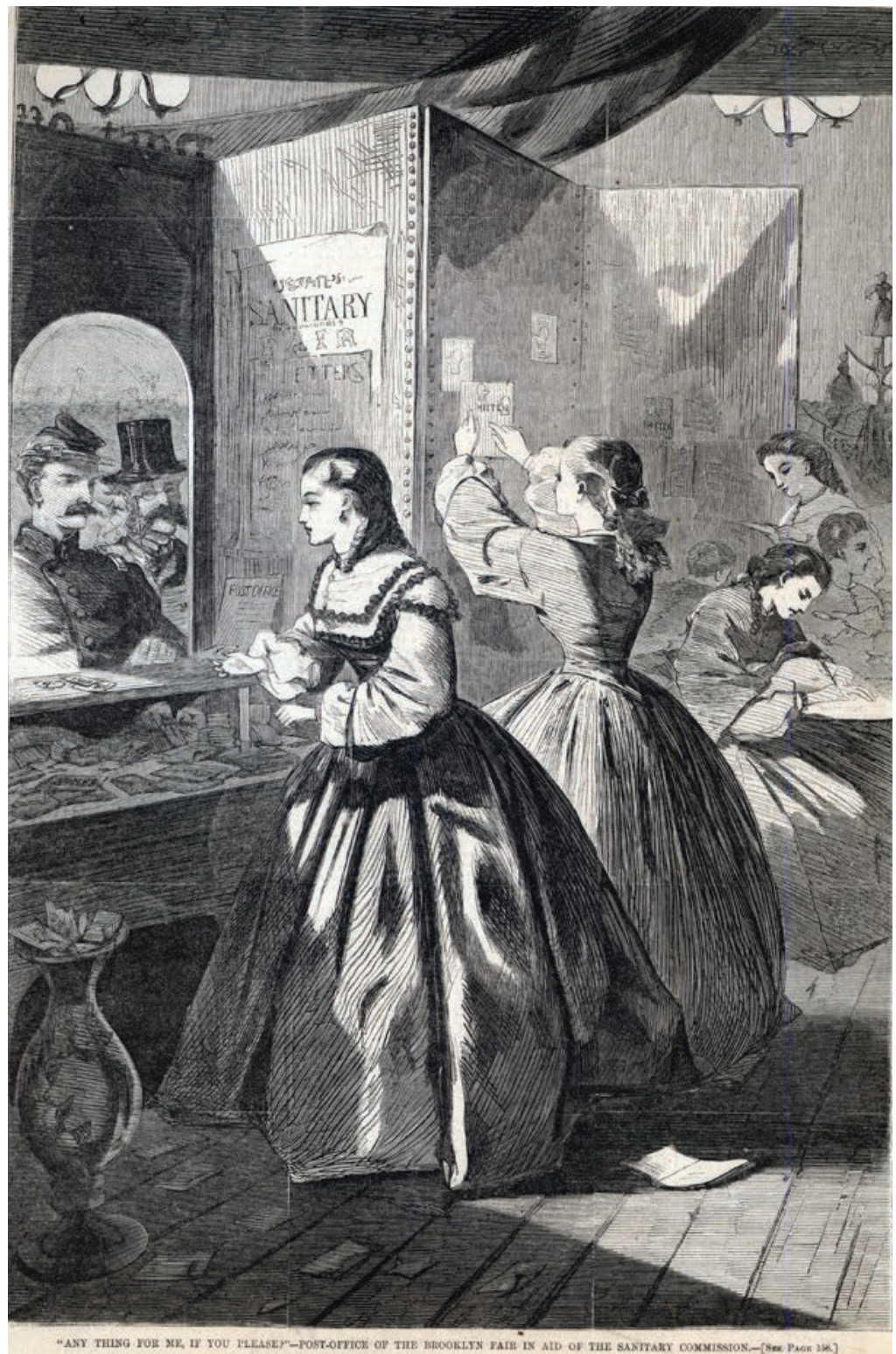

Figure 9. "Any Thing for Me, If You Please?" Post Office, Brooklyn and Long Island Fair, February, 1864. Broadside by Winslow Homer in Harper's Weekly, March 5, 1864, page 156. Kantor Collection on the U.S. Sanitary Commission and Sanitary Fairs, Special Collections and University Archives, Wichita State University Libraries. 


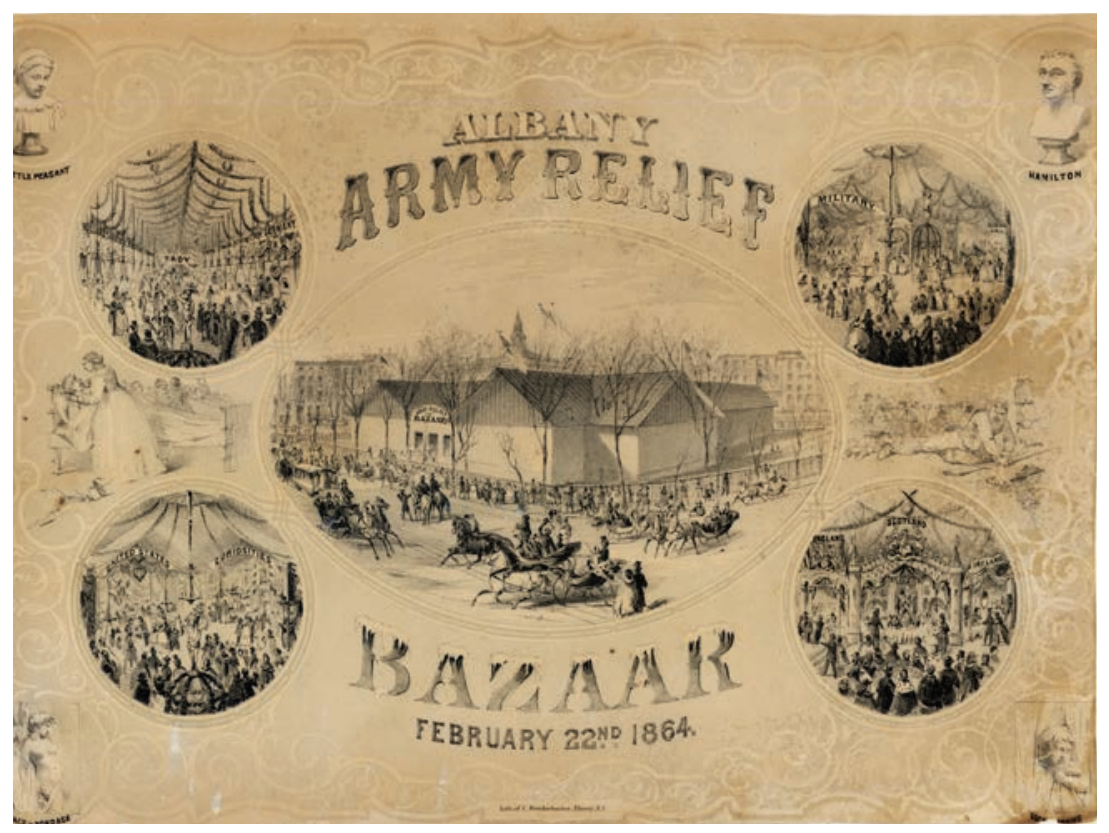

Figure 10. Albany Relief Bazaar broadside, February 22, 1864. Kantor Collection on the U.S. Sanitary Commission and Sanitary Fairs, Special Collections and University Archives, Wichita State University Libraries.

Each statue appeared in a corner of the broadside, framing scenes from the bazaar and images that depicted soldiers in battle and recuperating in a hospital. The large winter snow scene in the center featuring pedestrians and riders in horse drawn sleighs turned the disadvantage of cold weather into an opportunity to celebrate the locals' ability to master the elements and made even getting to and from the fairs a large-scale social occasion (see Figure 10). ${ }^{45}$

At the fairs, private collectors loaned artwork by European and American masters, and artists donated examples of their own work, such as the illuminated page at the Metropolitan Fair from the Artists of Philadelphia. This gift was a magnanimous gesture in light of the intense fair competition between the two cities (see Figure 11). ${ }^{46}$

45. Albany Army Relief Bazaar broadside, February 22, 1864, Kantor Sanitary Commission \& Sanitary Fairs Collection, Box 4, FF 19.

46. "Artists of Philadelphia" illuminated page, Metropolitan Fair, New York, April 1864, Kantor Sanitary Commission \& Sanitary Fairs Collection, Box 4, FF 1. 


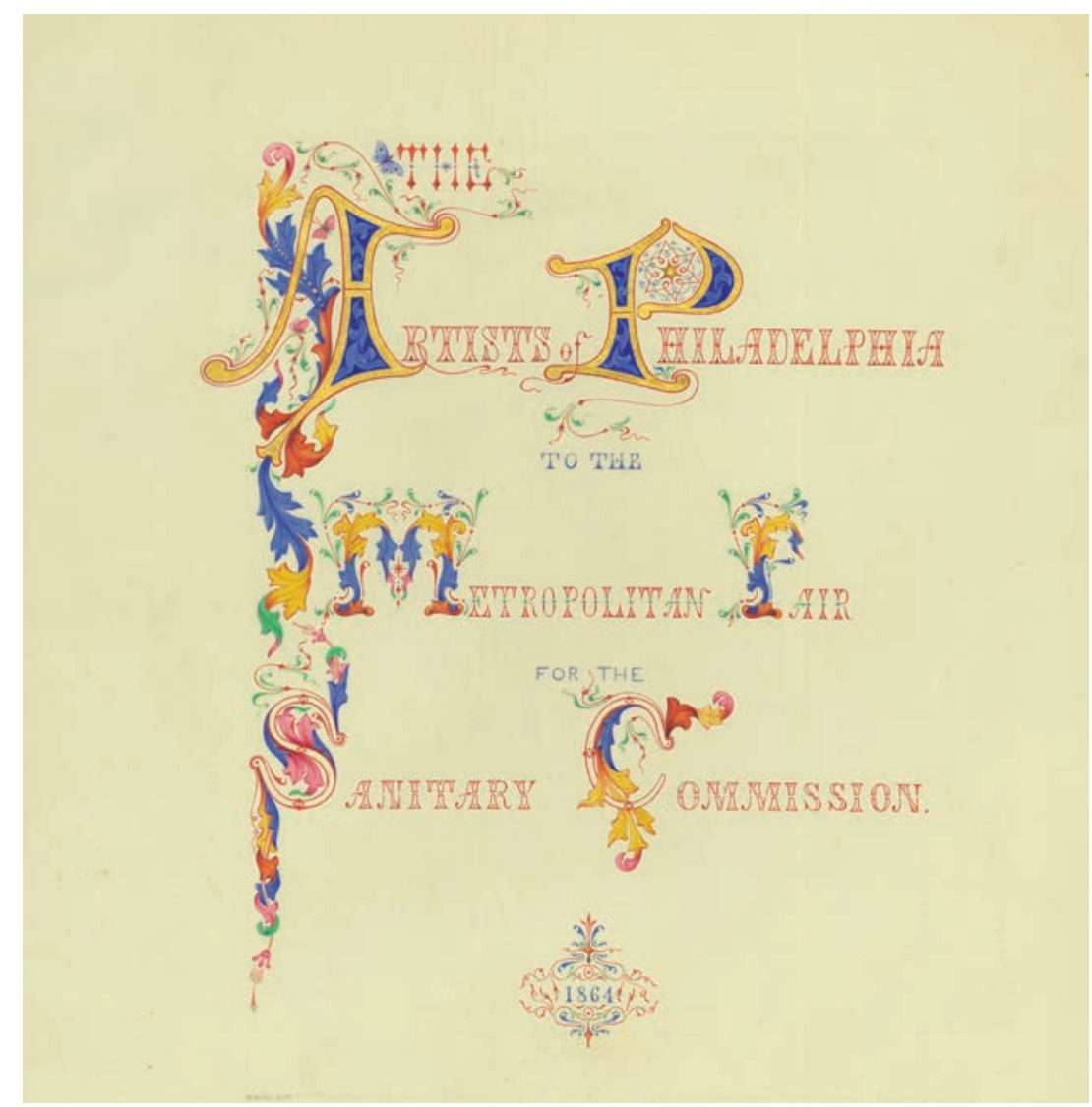

Figure 11. "Artists of Philadelphia" illuminated page, Metropolitan Fair, New York, April 1864. Kantor Collection on the U.S. Sanitary Commission and Sanitary Fairs, Special Collections and University Archives, Wichita State University Libraries.

Galleries displayed paintings and sculpture for viewing by people who rarely had such opportunities, and a catalog from the Metropolitan Fair shows the range and quality of artwork available for viewing and purchase. ${ }^{47}$ These exhibits were extremely well attended despite the fact that visitors paid the substantial sum of $\$ 1$, equivalent today to almost $\$ 15$, to see more than 350 masterpieces from European and American

47. Catalogue of the Art Exhibition at the Metropolitan Fair, in Aid of the U.S. Sanitary Commission (New York: Goupil \& Company, 1864). 


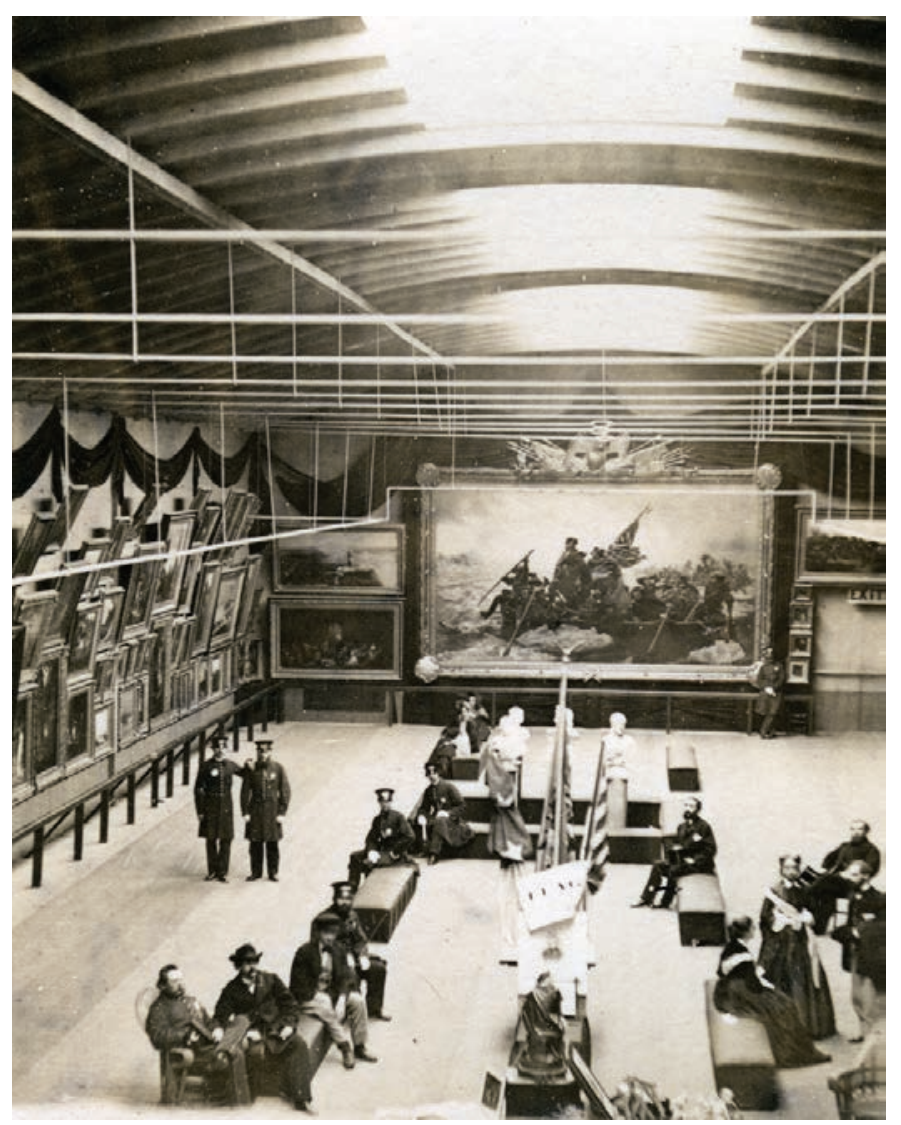

Figure 12. Fine Art Gallery, Metropolitan Fair, New York, April 1864, with a view of Emanuel Leutze's Washington Crossing the Delaware. Photograph by J. Gurney and Son in A Record of the Metropolitan Fair in Aid of the United States Sanitary Commission, page 98. Kantor Rare Book Collection, Special Collections and University Archives, Wichita State University Libraries.

artists, along with sculpture and photographs displayed in the Fine Art Gallery. Extant photographs credited to Mathew Brady show that fair organizers arranged the paintings with careful attention to the politics of patriotic display, and visitors were receptive to the messages of the paintings and the way they were hung. ${ }^{48}$ The centerpiece of the

48. See Worthington Whittredge Papers, Archives of American Art, Smithsonian Institution, http://www.aaa.si.edu/collections/worthington-whittredge-papers-9364/more, and the digitized version of Mathew Brady, Recollections of the Art Exhibition, Metropolitan Fair, New York (New 
exhibit, listed as "No. 1" and extensively described in the Metropolitan Fair's catalog, was Emanuel Leutze's Washington Crossing the Delaware (see Figure 12). ${ }^{49}$ The placement of this painting, the subject matter of which, according to the catalog, "marked the struggle of our forefathers for Independence," alluded to the struggle of those fighting for the Union and signified to viewers that they were the true heirs of the nation's revolutionary heroes. On the east and west walls, respectively, were Frederic Edwin Church's Heart of the Andes and Albert Bierstadt's Rocky Mountains, Lander's Peak. The display of these paintings opposite each other provided an allegorical contrast between South and North. ${ }^{50}$ At least some organizers were mindful that Church's composite southern landscape, which included Mount Chimborazo, also referenced the name of one of the so-called "seven hills" of Richmond, Virginia, the capital of the Confederacy, whose fierce refusal to surrender reinforced the importance of the fair.

The impact of the art gallery was so great that the daily newspaper of the Philadelphia fair, held two months later, printed reflections on the New York art gallery by an anonymous "Wounded Soldier" who concluded:

I turn from these rooms [of the Art Gallery and Arms and Trophies] with sorrow. I always left them with regret. They paid their quota of money nobly into the treasury. Many a poor fellow at this moment experiences the blessings which that money has bought, and yet I do not know if that money were the chief or greatest good done by the "Arms and Trophies" or the "Art Gallery," for what man or woman left either room without a nobler inspiration of Patriotism? ?1 $^{51}$

A few viewers did not interpret Bierstadt's painting as a symbol

York: M.B Brady, 1864) http://www.aaa.si.edu/collections/container/viewer/Book-emph-renderitalic-Recollections-of-the-Art-Exhibition-Metropolitan-Fair-New-York-emph-by-MathewBrady--285426.

49. Catalogue of the Art Exhibition at the Metropolitan Fair, 3-4.

50. For further discussion of the allegorical significance of the paintings and their placement as a depiction of the conflict between North and South, see Milroy, "Avenue of Dreams," 40-41, who compares the art exhibits at the New York and Philadelphia fairs.

51. "Recollections of the Fair in New York-No. 2 By A Wounded Soldier," in Our Daily Fare, Philadelphia, June 10, 1864, No. 3 (Philadelphia, Pa.: [s.n.], 1864-65), 18. 
of the North but, rather, as an iconographic representation of native life which they criticized because it did not depict examples of the "bloodthirsty savage" behavior they wanted to see. A letter to the artist published in the Metropolitan Fair's daily newspaper, Spirit of the Fair, expressed disappointment at what was missing in the painting:

Letter to Mr. Bierstadt.

Dear Mr. Bierstadt, admirable painter and true patriot:

Listen! We do so want to hear Indians, and the wigwams, and the wampum, and the shuffle dance, and the medicine jig, and to hear the war whoop, and to be scalped; wouldn't you be so very good as to have the windows opened in your beautiful skin palace, so that we could see and yet live. We will sacrifice our lives, if it be necessary; but, if not, please let in a little oxygen for our sakes. All the Ladies of Your Acquaintance. ${ }^{52}$

In contrast to the performances discussed above of Native dancers at the Metropolitan Fair and the "Indian" entertainer in the New England Kitchen at the Brooklyn Fair, the Natives in Bierstadt's painting show no signs of bellicose behavior. The content and tone of this letter suggest two possibilities. The "ladies," if they are to be believed, were expressing their own expectations for the artist's work or, perhaps, the letter was a parody of familiar native stereotypes and the newspaper editors included it as a source of amusement.

Acquisition and consumption were dominant activities of the fairs. Acquisition of a prodigious array of items, such as clothing, handicrafts, books, musical instruments, china, and souvenirs, and consumption of freshly prepared foods and beverages and other sensory experiences, such as demonstrations of heavy machinery and displays of luxury goods, drew substantial crowds. These activities offered visitors a dazzling range of choices and participatory experiences. They served a dual purpose, raising funds and instilling a sense of pride in the nation's abundance and productivity. Grand exhibition halls enclosed dozens of stalls displaying the finest goods donated by manufacturers, merchants, artisans, farmers, and homemakers. The Metropolitan Fair in particu-

52. Spirit of the Fair, Thursday, April 14, 1864, No. 9, 99. 
lar championed the importance of commerce in one of the articles that appeared in Spirit of the Fair:

New York is essentially national in interests, position, and pursuits. No one thinks of the place as belonging to a particular state, but to the United States. The revenue paid into the treasury, at this point, comes in reality, from the pockets of the whole country, and belongs to the whole country. The same is true of her sales and their proceeds....

Notwithstanding the generally fallacious character of the governing motive of all commercial communities, there is much to mitigate its selfishness. The habit of regarding the entire country and its interests with a friendly eye, and of associating themselves with its fortunes, liberalizes its minds and wishes, and confers a catholic spirit that the capital of a mere province does not possess.... This habit of generalizing in interests ... will account for the nationality of the great mart of a great and much extended country. The feeling would be apt to endure through many changes, and keep alive the connection of commerce even after that of the political relations may have ceased. ${ }^{53}$

A photo of the main hall at the Metropolitan Fair (see Figure 13) and an illustration of the main hall Bazaar at the Brooklyn and Long Island Fair (see Figure 14) testify to the commercial and agricultural vitality and industrial strength of the North in general and New York in particular. ${ }^{54}$ The displays and contributions in these images depict the talents of various producers and the devotion and financial sacrifice of visitors who admired and purchased the fruits of the nation's labor.

The dining areas elevated consumption to a grand patriotic occasion. Diners paid to sit down and experience eating a meal prepared according to the traditional recipes of early English or Dutch settlers whose perseverance provided the foundation for the nation's current

53. Spirit of the Fair, New York, April 7, 1864, No. 3, 30.

54. Main hall, Metropolitan Fair, New York, photograph by J. Gurney and Son, in A Record of the Metropolitan Fair in Aid of the United States Sanitary Commission, 156; main hall Bazaar, Brooklyn and Long Island Fair, History of the Brooklyn and Long Island Sanitary Fair, February 22, 1864, following 32. 


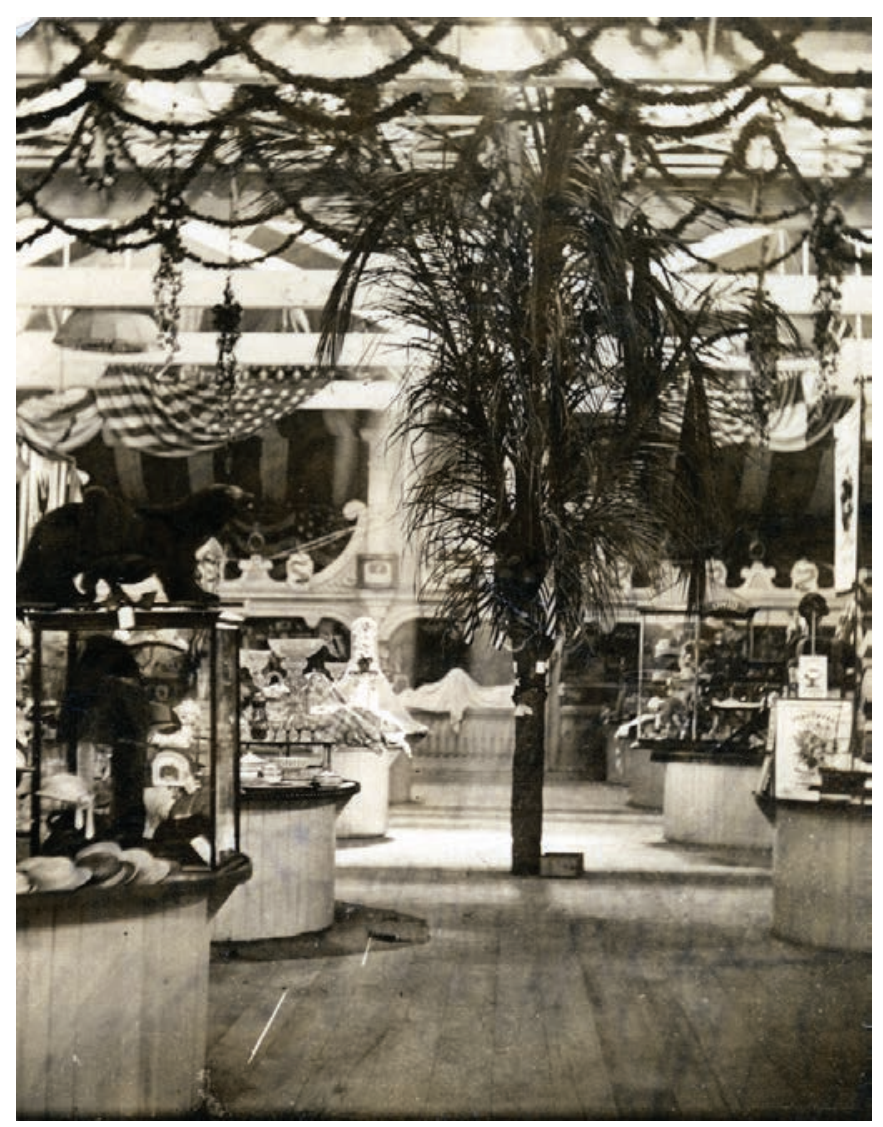

Figure 13. Main hall, Metropolitan Fair, New York, April 1864. Photograph by J. Gurney and Son in A Record of the Metropolitan Fair in Aid of the United States Sanitary Commission, page 156. Kantor Rare Book Collection, Special Collections and University Archives, Wichita State University Libraries.

abundance. Sometimes diners sat next to, or nearby, strangers from different walks of life, which created a sense of belonging and provided democratic opportunities for making social connections that develop from sharing a communal meal. This was particularly true at the Brooklyn and Long Island fair where diners ate "family style" with strangers, thereby breaking down, at least temporarily, the boundaries of Victorian-era public decorum (see Figure 15). ${ }^{55}$

55. History of the Brooklyn and Long Island Sanitary Fair, February 22, 1864, following 76. 


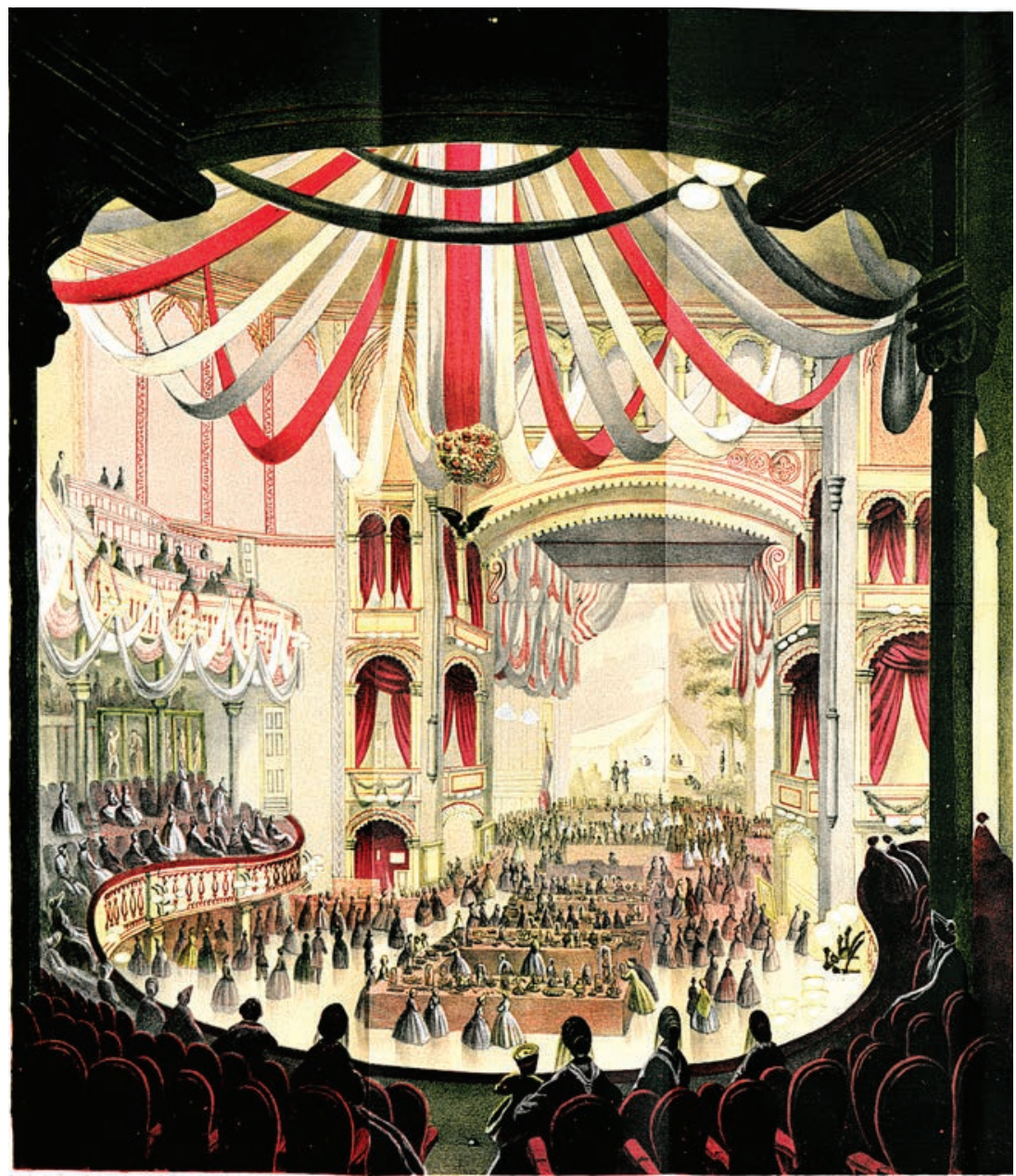

Figure 14. Main hall Bazaar, Brooklyn and Long Island Fair, in History of the Brooklyn and Long Island Sanitary Fair, February 22, 1864, following page 32. Kantor Rare Book Collection, Special Collections and University Archives, Wichita State University Libraries. 


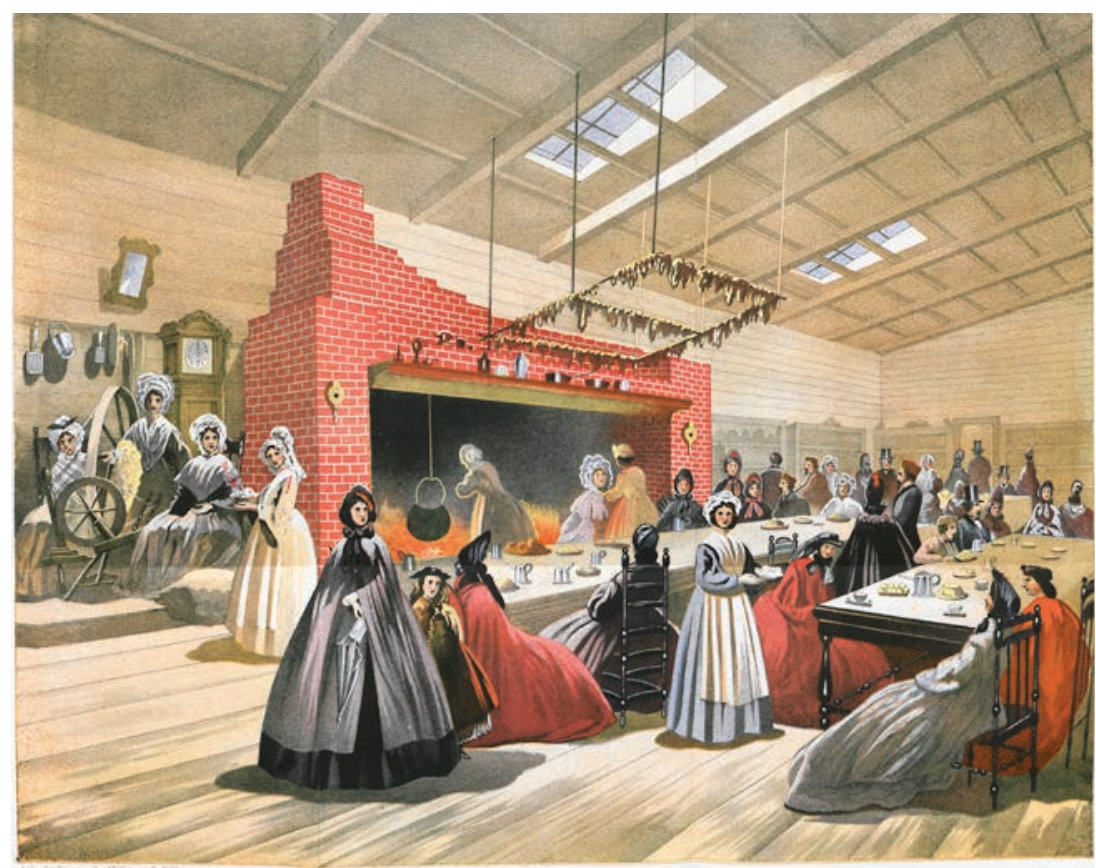

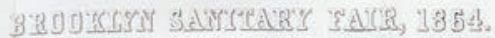

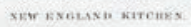

Figure 15. New England Kitchen, Brooklyn and Long Island Fair, in History of the Brooklyn and Long Island Sanitary Fair, February 22, 1864, following page 76. Kantor Rare Book Collection, Special Collections and University Archives, Wichita State University Libraries.

The fairs made children a focal point of their activities not just to raise funds but to garner parents' support and begin inculcating values of loyalty and service in the nation's youngest members. Many of the items on exhibit at the fairs provided entertainment for children, and, as the illustrations of the Children's Department at the Metropolitan fair indicate, considerable space was often set aside for children's play areas (see Figure 16). ${ }^{56}$ The ground plan of the Brooklyn fair shows the considerable space allotted to children's toys (see Figure 7). Children were also the focus of publicity given to fairs by local newspapers to

56. Exterior and interior views of the Children's Department of the Metropolitan Fair, New York, illustration in Demorest's New-York Illustrated News, April 23, 1864, vol. IX, no. 234, 409, Kantor Sanitary Commission \& Sanitary Fairs Collection, Box 6, FF 4. 


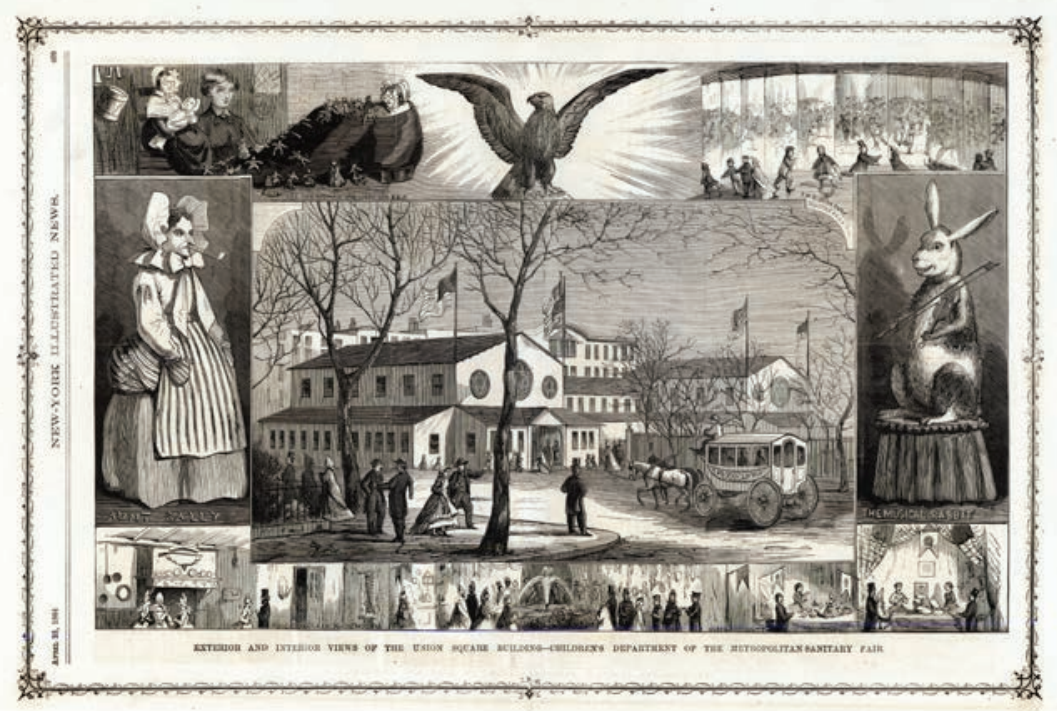

Figure 16. Exterior and interior views of the Children's Department of the Metropolitan Fair, New York, in Demorest's New-York Illustrated News, April 23, 1864, page 409. Kantor Collection on the U.S. Sanitary Commission and Sanitary Fairs, Special Collections and University Archives, Wichita State University Libraries.

encourage children to contribute to the fairs through their own efforts. Demorest's New-York Illustrated News displayed the contribution of a fictitious Tom Punkins to the Metropolitan Fair of a kite in the shape of Abraham Lincoln's head (see Figure 17). ${ }^{57}$ The artist, whose identity is unknown, managed to deftly convey, through a child's toy that is both strong and vulnerable, the very human terms in which Lincoln was viewed at the time, untinged with the hero warship that his assassination and collective memory would later imbue. Like a kite that could soar, Lincoln was perched high in the esteem of many Northerners for the eloquence of his words and his steely determination. Popular frustration with the war and uncertainty over its aftermath, however, also made him hover perilously close to the winds of defeat that could cost him

57. “Tom. P. An Abe[1] Lincoln Kite," illustration in Demorest's New-York Illustrated News, April 23, 1864, vol. IX, no. 234, 404, Kantor Sanitary Commission \& Sanitary Fairs Collection, Box 6, FF 4. This is one of the few images of Abraham Lincoln in the Kantor Collection. 


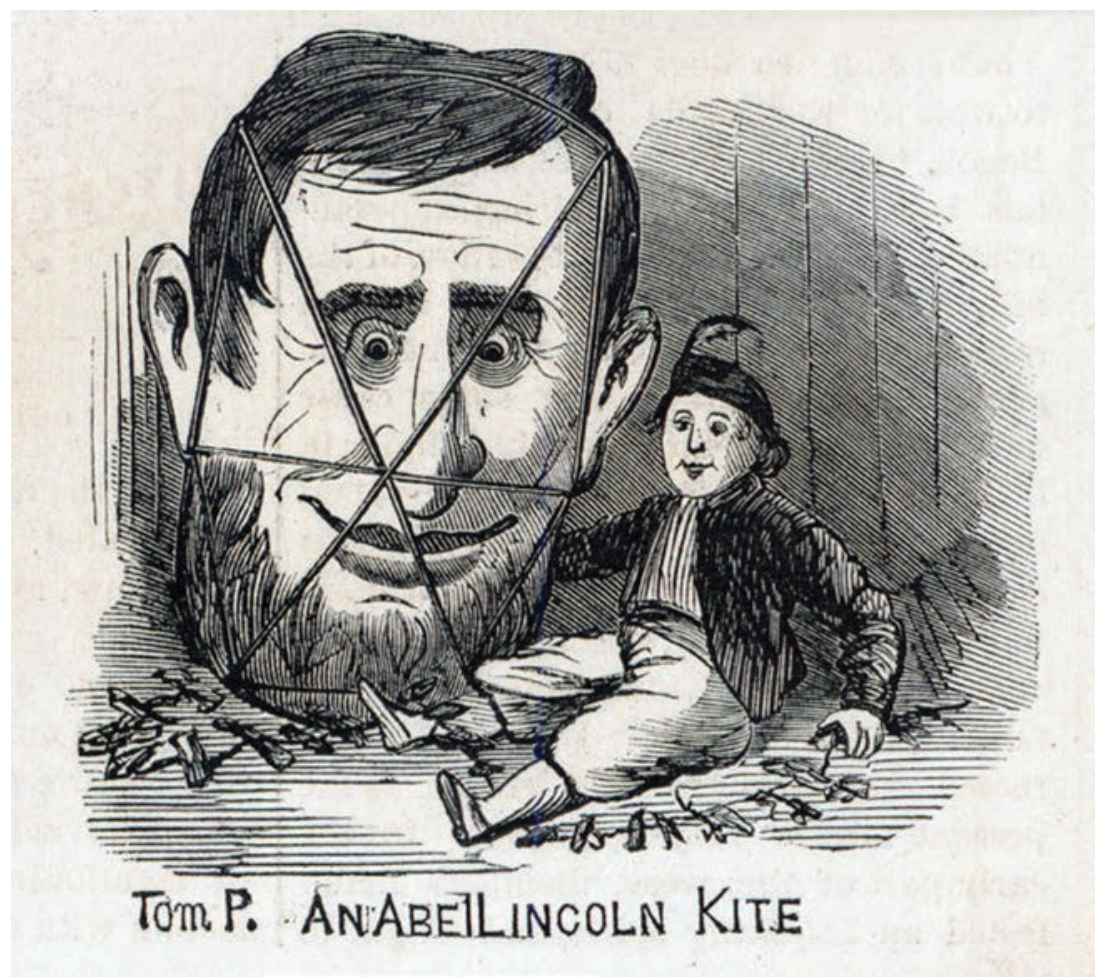

Figure 17. "Tom. P. An Abe[l] Lincoln Kite," publicity for the Metropolitan Fair, New York, in Demorest's New-York Illustrated News, April 23, 1864, page 404. Kantor Collection on the U.S. Sanitary Commission and Sanitary Fairs, Special Collections and University Archives, Wichita State University Libraries.

reelection. In contrast to other images of Lincoln in the collection, this image is the only one that made him an object of humor. Significantly, it was intended to appeal to children and produced by a newspaper rather than as official fair publicity. ${ }^{58}$

58. The other images of Lincoln depict him in conventional portraits, including an allegorical representation of the progress of the republic with a portrait of Lincoln in the center, which was displayed in the New England Kitchen at the Brooklyn and Long Island Fair. Unlike the kite, this image maintains the solemnity of other portraits. It was sold in one hundred shares of $\$ 5$ each to subscribers and sent to Lincoln, History of the Brooklyn and Long Island Fair, February 22, 1864, 76. The images of George Washington reveal a similar reverential style of conventional portraits and, in one example, as a statue draped in Roman garb. The only humorous depiction of Washington was in the tableaux of characters in the kitchen entertainments at the Brooklyn fair. 
During the Civil War, the sanitary fairs fused the need for providing medical and humanitarian care for Union soldiers with the opportunity to stage a series of national pageants celebrating the vitality of America's commitment to an idea of nationhood that united disparate individuals into a common purpose of service to something greater than themselves. The importance of this theme is underscored in an essay in The Canteen, the newspaper produced by the Albany sanitary fair:

The great Sanitary Fairs ... have made us look beyond that narrow sphere. We have been selfishly devoted to personal interests; they have caused us to recognize the fact, that humanity has large claims upon us....

In all this, these Fairs but carry still farther the influence of the war itself... That in which we are now engaged, will stamp itself upon all the future of our country, not only on its political history, but with equal force on its moral character.

It has already purified and elevated us to a degree which would surprise the acutest observers of three years ago. ... The bloody battle-field, the funeral procession, the desolate fireside, have produced a conviction and a determination which nothing less severe could have accomplished. They have brought the people to a frame of mind ... which will not suffer wrong and injustice to triumph through a mistaken policy, and which will not allow selfishness and avarice to be the controlling principles of life. ${ }^{59}$

The diligent effort of this appeal to frame the lessons of the fairs and the war in lofty prose cannot mitigate its underlying obfuscation. The purported author, "Mr. Smith," does not articulate the nature of the wrong and injustice that the fairs and the war must not suffer to triumph. Nor does he allude to the thorny issues of a growing class conflict, the uncertainty over the terms of ending slavery, and the treatment of former slaves.

Yet, unlike the Sanitary Commission, which vainly tried to remake

59. “The Lessons of the Fair and the War," edited by "Mr. Smith," in The Canteen, Albany, March 4, 1864, 126, reprinted by The New York State Library, http://www.nysl.nysed.gov/library/features/ ep/pdfs/canteennewsletter.pdf. 
human nature during the Civil War, the organizers of the sanitary fairs, including those held in New York, succeeded in raising unprecedented funds for soldiers' care and comfort because they made this objective part of a larger program of national renewal. The fairs' spectacle of national glory, displayed amidst an unparalleled array of cultural, commercial, and military wonders, galvanized ordinary men, women, and children to volunteer their time, energy, and material resources to a higher ideal of nationhood in a way they had never shown before and, with the possible exception of World War II, would not do so again. 